\title{
HOW DO SMALL BUSINESS MANAGERS INFLUENCE EMPLOYEE SATISFACTION AND COMMITMENT?
}

\author{
Janine Krüger: Department of Business Management, Nelson Mandela Metropolitan University \\ Chantal Rootman: Department of Business Management, Nelson Mandela Metropolitan University
}

\begin{abstract}
Purpose: The purpose of this research is to scrutinise motivational factors that may influence the levels of satisfaction and
\end{abstract} commitment of small business employees.

Problem investigated: An unmotivated workforce leads to dissatisfaction and low commitment levels among employees. Possible consequences of these unproductive trends include higher costs, business closures and a negative effect on a country's economy. Employee satisfaction and employee commitment are thus vital for the success of any business. It is essential for business managers to keep their employees satisfied and committed to the business. In order for business managers to motivate their employees to keep them satisfied and committed, they need to know how to motivate employees. A number of factors influence employee satisfaction and employee commitment, which include working conditions, managerial abilities, employee participation, company policies, recognition and feedback, as well as job interest and job importance. Managers should know how to apply each of these factors to ensure that employees are satisfied and committed.

Methodology: A quantitative research approach was followed using a self-administered questionnaire. This measuring instrument consisted of three sections covering the biographical information of respondents, statements on motivational factors, and statements about satisfaction and commitment. A five-point Likert-type scale, ranging from strongly disagree to strongly agree, was applied. Simple random sampling was used to elicit the responses of 444 respondents from small businesses in the Nelson Mandela Metropole in South Africa. Cronbach Alpha coefficients were calculated to measure the internal consistency and reliability of the measuring instrument. Descriptive statistics, Pearson correlation coefficients and simple linear regression analyses were used to analyse the data.

Findings and implications: The research revealed that significant positive relationships exist between all the motivational factors and satisfaction, as well as with commitment. The strongest positive relationships exist between the independent variable job interest and importance and both the dependent variables. The weakest relationships exist between the independent variable rewards and both the dependent variables. Levels of satisfaction and commitment should continually be developed and improved through management training about the application of motivational factors. Small businesses should implement the motivational factors discussed in this research in creative ways, in order to have a positive effect on the satisfaction and commitment levels of employees.

Originality and value of the research: This research focused on what small business managers should concentrate on when motivating their employees. Small business managers should also realise that motivation cannot be separated from employee satisfaction and commitment. The value of the research is that when small business managers pay more attention to these factors as identified in this study, it may lead to better business performance in the long run. With regard to the originality of this research, previous research has focused mainly on motivational theories without reaching a conclusion or highlighting possible strategies that could be used by small businesses to motivate employees.

Key words and phrases: SMMEs, employee satisfaction, employee commitment, business performance.

\section{INTRODUCTION}

Small and medium-sized business enterprises (SMEs) are internationally regarded as the main engine of global economic activity. These enterprises are important for a number of reasons, such as job creation through growth, social stability, and wealth creation for countries (Daft, 2008:175-180; Reece, 2001:196; World Business Council for Sustainable Development, 2007). According to Lewis (2002), SMEs tend to be more labour-intensive than larger firms, and $55 \%$ of the total workforce of South Africa is employed in SMEs. Lewis (2002) states that the SMEs sector in South Africa contributes substantially to competitiveness among firms in terms of employment, creation and innovation. Vil-Nkomo (2005) concurs that SMEs are the largest 
employment creators and innovators in the economy. This is also evident if one considers that SMEs pay $42 \%$ of South Africa's wage bill.

In developing countries such as South Africa, more than $90 \%$ of all enterprises outside the agricultural sector are SMEs, generating a significant portion of the gross domestic product (GDP) (World Business Council for Sustainable Development, 2007). According to Statistics SA (Wadula, 2005), out of a total of 223505 enterprises registered in South Africa in 2004, 218909 were classified as SMEs. Munyanyiwa (2009) concurs that SMEs are important for economic growth, since SMEs contribute between $30 \%$ and $40 \%$ of South Africa's gross domestic product, and over $70 \%$ in employment.

According to Watson (2003), it would be possible to reduce the failure rate of SMEs if business owners/managers had access to appropriate advice, such as motivational strategies to be implemented in their firms, as well as strategies to improve managerial skills (for example interpersonal skills). According to Sheldon (2006), a number of factors influence the motivational levels of employees, which will eventually influence employee satisfaction and commitment. These factors include autonomy, responsibility, recognition, development, teamwork, career opportunities and rewards.

To improve the survival rate of SMEs, it is therefore important to increase the knowledge base of owners/managers about what factors motivate employees, so as to ensure employee satisfaction. Bosch, Tait and Venter (2006:663) agree that it is absolutely vital to the success of SMEs to create an environment in which employees are motivated and ultimately satisfied. It is therefore imperative that managers learn how to motivate employees, and more important, how to keep them motivated. According to Cronjè, Du Toit and Motlatla (2000:154) and Ireland, Hoskisson and Hitt (2009:341, 351), understanding employees' needs and motivating them has become an essential skill for managers. Only once owners/managers understand the different motivational factors that employees value, will they be able to influence their employees' behaviour to the best interest of the business.

According to Macleod (1999:84-85), it is important for owners/managers to realise that if employees are not motivated, the SMEs will be faced with numerous problems, such as high employee turnover, high absenteeism, increased levels of sick-leave taken, low productivity, unwillingness to work overtime, and arriving late for work. All these factors will lead to lower productivity and higher costs, both of which the firm would like to avoid. The focus of this study will therefore be on the motivational theories and the factors that will motivate SME employees, enhancing their satisfaction and commitment levels.

\section{PURPOSE AND OBJECTIVES OF THE STUDY}

The primary objective of this study was to investigate the predetermined factors motivating employees, in order to ensure improved employee satisfaction and commitment levels in small businesses in the Nelson Mandela Metropole in South Africa.

A number of secondary objectives were pursued in order to achieve the primary objective of this study. These secondary objectives were:

- to conduct a secondary literature overview of small businesses in South Africa, as well as motivational factors, by investigating the different motivational theories;

- to capture, analyse, interpret and report on the data gathered from the completed questionnaires; and

- to make recommendations to small business managers/owners by providing possible motivational strategies to ensure improved levels of employee satisfaction and commitment.

\section{PROBLEM INVESTIGATED}

The majority of an individual's life is spent at the workplace. On average, assuming a person starts to work at the age of 18 and retires at 65, he/she will work for approximately 47 years. Considering this amount of time in the workplace, it is important that he/she should be satisfied with the career path chosen. This sentiment is 
shared by Daft (2008:38-30), who states that a job must be challenging and meaningful for an individual, and there must be a sense of importance attached to the job.

It is important that employees should be motivated. Motivating employees is one of the most vital activities that managers have to perform, but it is also one of the most challenging. What motivates one individual does not necessarily motivate another. It is therefore a complex task to determine what motivates whom, and how to apply such motivational factors in practice (Robbins \& Coulter, 1999:530). Motivation is a very complicated issue, and there is no single magic formula that can be used to motivate every individual. It is therefore important to investigate motivation in more depth, in order to advise small businesses about which motivational factors need to be applied to the fullest extent (Oldcorn, 1989:159).

In previous research there is a gap, seeing that most literature sources address the topic of motivation merely by concentrating in depth on motivational theories, without reaching a conclusion or highlighting strategies that could be used by small businesses to motivate employees (Goodworth, 1984:113). Some managers believe that only one motivational theory is necessary to develop productive employees. Other managers believe that some individuals are born motivated, while others simply are not. What many researchers do not realise is that no single theory will explain the complex issue of motivation; however, by studying all the different theories, something can be learned from each of them (Carrell, Grobler, Elbert, Marx, Hatfield \& Van der Schyf, 1998:105).

The issue of motivating employees has quite an impact on the performance of small businesses. Management's task is to get the work done by the employees. In order to motivate them, it is crucial that there should be a workforce that will co-operate with the manager. Without motivation, employees will tend to be less productive and slower to complete the job. The low productivity of employees can lead to an unsuccessful end result for the business, as all businesses need productive and motivated human resources in order to be successful and grow (Daft, 2008:622-624; Goodworth, 1984:120). A sound knowledge of motivation is one of the most important factors that lead to improved work performance (Smit \& Cronjè, 2002:343). If managers do not have the knowledge and the skill to motivate employees, they will not be able to reach their business goals and make a success of the business, as all businesses need an effective workforce in order to survive.

It is certain that when this issue of motivation is addressed, there will be beneficial gains for both the employer and employee. As stated above, management gets the work done through the employees. Individuals are complex; it is not always easy to determine what motivates them. However, the better management understands what motivates an individual and the more effectively management applies the appropriate motivational factors, the more the individual's behaviour will favour the business. If the behaviour of employees is successfully influenced, productivity can be increased. If a business' workforce is motivated and satisfied, the implementation of management decisions and the performance of employees can be improved (Louw \& Venter, 2006:424; Cronjè et al., 2000:154).

By studying the motivational theories, management will also know the "how, why and what of human behaviour". The end result of this study will make it easier for managers to identify what motivates the employees of small businesses and how the implementation of such motivational factors can lead to higher levels of satisfaction and commitment among their employees. However, there is some confusion with regard to the extent of the problem, and many managers are unaware of the seriousness of the issue of unmotivated employees. Even though management knows that employees are of great importance to the business, they are often not aware of the factors that cause their employees to be unmotivated or dissatisfied. If management does not acknowledge that a certain problem exists, employees will not be motivated, and therefore these employees will be unproductive, disloyal to the business, and non-committed (Mol, 1993:44).

There is a great need for motivational strategies in small businesses. This need is often greater than one would expect because of the limitations of resources in small businesses. Managers in small businesses are often so preoccupied with the core operational concerns that by the time they realise that their workforce has 
a negative attitude towards the business, commitment has already been lost (Lynas \& Dorrian, 1987:24). Therefore, this study will address the problems concerning motivation in small businesses. The problem statement can now be described as follows:

To investigate the motivational factors (independent variables) that may lead to increased levels of satisfaction and commitment (dependent variables) of employees in small businesses.

\section{RESEARCH METHODOLOGY}

A positivistic paradigm was adopted for this study, in order to satisfy the problem statement and research objectives. A "positivistic paradigm" is a research philosophy that is associated with deductive reasoning, which has been adopted from the natural sciences (Collins \& Hussey, 2003:13).

Primary and secondary data were used for this study. In order to obtain the primary research data, a selfadministered questionnaire was used. Textbooks, the Internet and journal articles were used in order to obtain secondary data. The target population for the empirical investigation included respondents from small businesses in the Nelson Mandela Metropole. A self-developed and self-administered questionnaire (the measuring instrument) was distributed to solicit the responses of 444 respondents from various small businesses in this area. Simple convenience sampling was used.

The questionnaire consisted of three sections. Section A collected biographical and demographical data of the respondents and their firms. Sections B and C consisted of statements based on the literature overview as presented in the problem investigated. Statements were phrased for each of the factors that might have an effect on employee satisfaction and commitment. A five-point Likert-type scale ranging from strongly disagree (1) to strongly agree (5) was used. Section B specifically focused on the different factors that might have an influence on employee satisfaction and commitment, while Section C collected data on employee satisfaction and employee commitment.

To determine the reliability and the empirical results of the hypothesised relationships amongst the factors investigated in the study, the measuring instrument used and the data gathered from the sample were subjected to thorough analyses. The computer programmes Microsoft Excel and SPSS were used for the statistical analysis of all data.

Data analysis relating to the reported empirical results was conducted in four phases.

- Firstly, descriptive statistics were calculated. Burns and Burns (2008:8) and Lind, Marchal and Wathen (2008:6) have described descriptive statistics as the transformation of raw data into a form that will make it easily understandable, in an organised, presentable and analysed format. Specifically, descriptive statistics such as the mean and frequency distribution were calculated, to summarise the sample data distribution. The biographical and demographical data of both the respondents and the businesses were conveyed through frequency distributions, and the extent to which the predetermined motivational factors were present in the respondents' current work situations was indicated by the mean values.

- Secondly, Cronbach alpha correlation coefficients were calculated to quantify the internal reliability of the self-developed and self-administered questionnaires. "Reliability" relates to the extent to which a particular data collection approach will yield the same result on different occasions (Lancaster, 2005:72). Cronbach alpha correlation coefficients range from 0 to 1 . The test should yield a Cronbach alpha correlation coefficient greater than 0.7 to be regarded as reliable (Burns \& Burns, 2008:417; Hair, Babin, Money \& Samouel, 2003:172).

- Thirdly, Pearson correlation coefficients were computed to establish whether relationships between the predetermined motivational factors (independent variables) and employee satisfaction and commitment (dependent variables) existed. The Pearson correlation coefficient can be used to determine the strength or degree of a relationship between two variables. This coefficient ranges from -1.00 (perfect negative) to +1.00 (perfect positive) where zero (0) indicates no relationship at all (Lind et al., 2008:393-394; De Vos, Strydom, Fouché \& Delport, 2005: 241-242). 
- Lastly, a simple linear regression analysis was undertaken to determine which predetermined motivational factors (independent variables) explained significant variations in employee satisfaction and commitment (dependent variables). The correlation coefficient $(r)$ ranges from +1.0 (perfect positive correlation) to -1.0 (perfect negative correlation), and zero (0) indicates no correlation (Zikmund, 2003:565).

\section{HYPOTHESES}

To give effect to the problem statement, two groups of hypotheses, based on the literature review, were constructed. The two groups of hypotheses tested whether relationships existed between the independent variables (seven predetermined motivational factors) and the two dependent variables (employee satisfaction and commitment). Figure 1 depicts the conceptual model that would be tested in the empirical study.

\section{Figure 1: Seven motivational factors which may influence employee satisfaction and commitment}

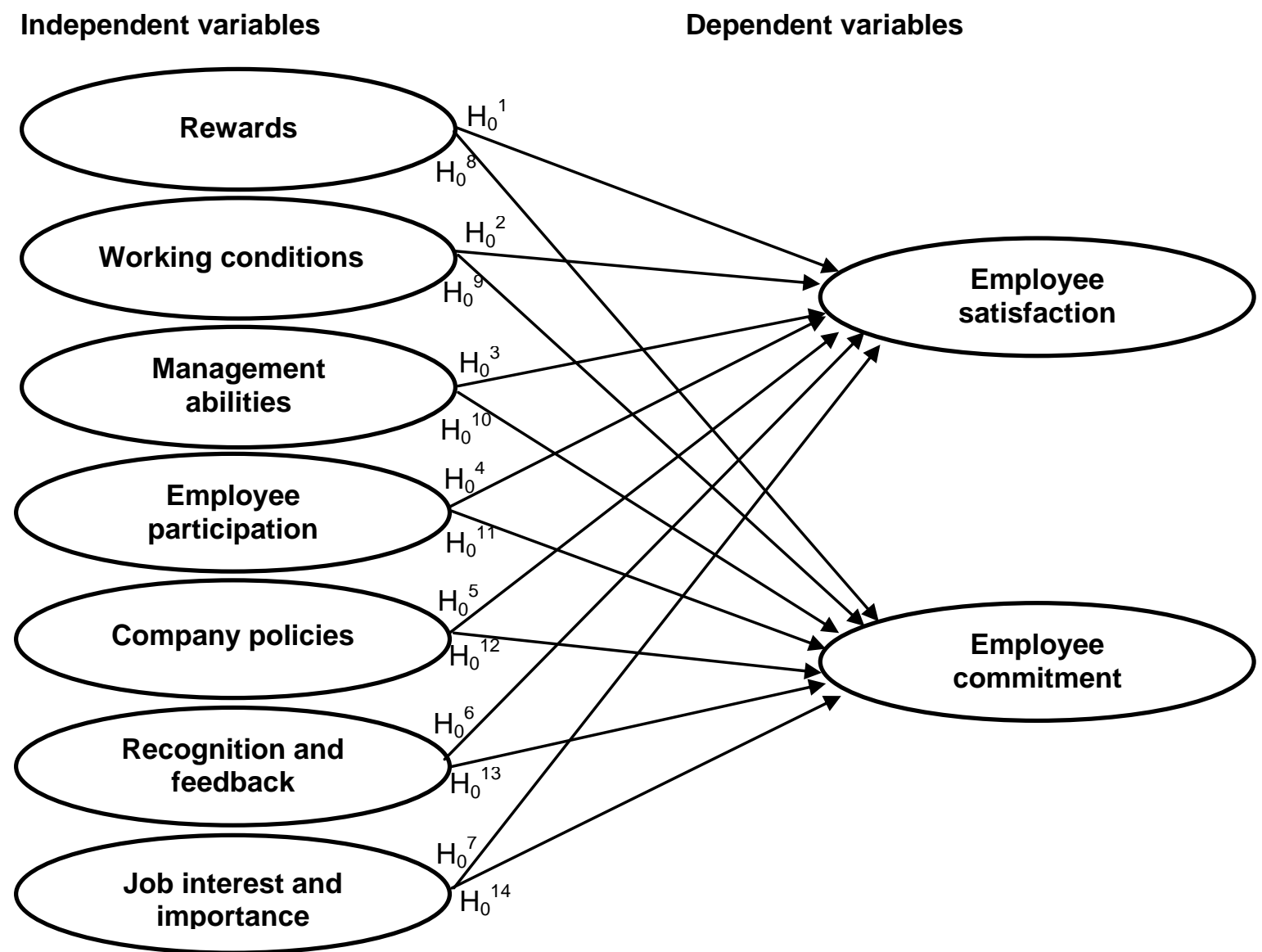

The first group of hypotheses that were constructed to determine whether relationships between the seven predetermined motivational factors and employee satisfaction existed, and were therefore tested in the empirical investigation.

$\mathrm{H}_{0}{ }^{1} \quad$ No relationship exists between rewards and employee satisfaction.

$\mathrm{H}_{0}^{2} \quad$ No relationship exists between working conditions and employee satisfaction.

$\mathrm{H}_{0}{ }^{3} \quad$ No relationship exists between management ability and employee satisfaction. 
$\mathrm{H}_{0}{ }_{5} \quad$ No relationship exists between employee participation and employee satisfaction.

$\mathrm{H}_{0}^{5} \quad$ No relationship exists between company policies and employee satisfaction.

$\mathrm{H}_{0}{ }^{6} \quad$ No relationship exists between recognition and feedback and employee satisfaction.

$\mathrm{H}_{0}^{7} \quad$ No relationship exists between job interest and importance and employee satisfaction.

The second group of hypotheses that were formulated aimed to determine whether relationships existed between the seven predetermined motivational factors and employee commitment, and were also tested in the empirical investigation.

$\mathrm{H}_{0}^{8} \quad$ No relationship exists between rewards and employee commitment.

$\mathrm{H}_{0}{ }^{9} \quad$ No relationship exists between working conditions and employee commitment.

$\mathrm{H}_{0}{ }^{10} \quad$ No relationship exists between management ability and employee commitment.

$\mathrm{H}_{0}{ }^{11} \quad$ No relationship exists between employee participation and employee commitment.

$\mathrm{H}_{0}^{12}$ No relationship exists between company policies and employee commitment.

$\mathrm{H}_{0}{ }^{13}$ No relationship exists between recognition and feedback and employee commitment.

$\mathrm{H}_{0}{ }^{14}$ No relationship exists between job interest and importance and employee commitment.

From the literature review, it was found that seven motivational factors influence employees' motivational levels. Furthermore it was found that motivation influences employee satisfaction and commitment. Based on these findings from literature, a conceptual model was developed. Therefore this study focused on determining whether relationships existed between these predetermined motivational factors and employee satisfaction and commitment.

\section{ANALYSIS AND INTERPRETATION OF FINDINGS}

\section{Reliability}

To evaluate the internal reliability of the questionnaire, the Cronbach alpha correlation coefficients were calculated to evaluate the internal reliability of the measuring instrument, namely the self-administered questionnaire. The obtained scores are indicated in Table 1.

\section{Table 1: Cronbach alpha correlation coefficients for motivational factors}

\begin{tabular}{|l|l|}
\hline Motivational factors & Cronbach alpha coefficients \\
\hline Rewards & $\mathbf{0 . 7 5 8 6}$ \\
\hline Working conditions & 0.8548 \\
\hline Management abilities & 0.8878 \\
\hline Employee participation & $\mathbf{0 . 9 2 9 1}$ \\
\hline Company policies & 0.8901 \\
\hline Recognition and feedback & 0.8615 \\
\hline Job interest and importance & 0.8202 \\
\hline
\end{tabular}

The Cronbach alpha coefficient is a numerical value indicating reliability. It measures the internal consistency among a set of items. In order to be classified as reliable, the recommended reliability coefficient is 0.70 or above. The higher the Cronbach alpha correlation coefficient, the more reliable the test is (Burns \& Burns 2008:417). For the purpose of this study, the cut-off value of 0.70 was used to indicate reliability.

As evident from Table 1, all the factors had Cronbach alpha correlation coefficients in excess of the recommended 0.70 . The scores were within the range 0.7586 (rewards) to 0.9291 (employee participation). These figures indicate the reliability of the phrased items to measure what they were intended to measure. Therefore, the measuring instrument used in this study, the self-developed questionnaire, could be taken as reliable, as all the Cronbach alpha correlation coefficients (indicated in Table 1) were above 0.70 . 


\section{Biographical results of respondents}

The majority of respondents were females (64\%) in the age group 20-29 years (48\%), as can be seen in Table 2. The majority of respondents were from the white (38\%) and black $(36 \%)$ population groups. The majority of respondents had a high level of education, with $55 \%$ having obtained a tertiary qualification. However, the majority of respondents had working experience of less than 10 years $(61 \%)$. Mostly, the respondents had been employed in the current business for less than 10 years $(89 \%)$.

\section{Demographical results of businesses}

In Table 3 it is evident that there was a relatively even distribution between family- $(55 \%)$ and non-family $(41 \%)$ businesses. Most of the sample businesses had been in existence for less than 10 years (59\%) and the majority of businesses employed less than $10(64 \%)$ employees. Close corporations (31\%) and sole traders $(30 \%)$ were the most popular forms of business, and the most common industry in which the businesses operated was the service industry (41\%).

\section{Table 2: Biographical data of respondents}

\begin{tabular}{|c|c|c|}
\hline Items & Frequency & $\%$ \\
\hline Gender & 444 & 100 \\
\hline Male & 157 & 35 \\
\hline Female & 282 & 64 \\
\hline Missing values & 5 & 1 \\
\hline Age group & 444 & 100 \\
\hline$>20$ & 25 & 6 \\
\hline $20-29$ & 214 & 48 \\
\hline $30-39$ & 103 & 23 \\
\hline $40-49$ & 63 & 14 \\
\hline $50-59$ & 26 & 6 \\
\hline $60+$ & 8 & 2 \\
\hline Missing values & 5 & 1 \\
\hline Ethnic group & 444 & 100 \\
\hline Asian & 22 & 5 \\
\hline Black & 161 & 36 \\
\hline Coloured & 78 & 18 \\
\hline White & 168 & 38 \\
\hline Not willing to say & 10 & 2 \\
\hline Missing values & 5 & 1 \\
\hline Tertiary qualification & 444 & 100 \\
\hline Qualification & 245 & 55 \\
\hline No qualification & 186 & 42 \\
\hline Missing values & 13 & 3 \\
\hline Total working experience & 444 & 100 \\
\hline$<10$ & 271 & 61 \\
\hline $11-20$ & 77 & 17 \\
\hline $21-30$ & 39 & 8 \\
\hline $31-40$ & 17 & 4 \\
\hline $41-50$ & 2 & 1 \\
\hline $51-60$ & 2 & 1 \\
\hline Missing values & 36 & 8 \\
\hline Length of employment with current employer & 444 & 100 \\
\hline$<10$ & 394 & 89 \\
\hline $11-20$ & 29 & 6 \\
\hline $21-30$ & 9 & 2 \\
\hline Missing values & 12 & 3 \\
\hline
\end{tabular}


Table 3: Demographical data of businesses

\begin{tabular}{|c|l|l|}
\hline Items & Frequency & $\%$ \\
\hline Family VS non family business & $\mathbf{4 4 4}$ & $\mathbf{1 0 0}$ \\
Family business & 244 & 55 \\
Non family business & 184 & 41 \\
Missing values & 16 & 4 \\
\hline Existence of business & $\mathbf{4 4 4}$ & $\mathbf{1 0 0}$ \\
<10 & 261 & 59 \\
$11-20$ & 87 & 19 \\
$21-30$ & 46 & 10 \\
$31-40$ & 18 & 4 \\
$41-50$ & 6 & 1 \\
$51-60$ & 3 & 1 \\
$61-70$ & 0 & 0 \\
$71-80$ & 2 & 1 \\
Missing values & 21 & 5 \\
\hline Number employees & $\mathbf{4 4 4}$ & $\mathbf{1 0 0}$ \\
<10 & 285 & 64 \\
$21-20$ & 64 & 14 \\
$31-40$ & 48 & 11 \\
$41-50$ & 17 & 4 \\
Missing values & 9 & 2 \\
Soriness & 21 & 5 \\
\hline Pole trader & $\mathbf{4 4 4}$ & $\mathbf{1 0 0}$ \\
Partnership & 131 & 30 \\
Private company & 45 & 10 \\
Close corporation & 57 & 13 \\
Trust & 137 & 31 \\
Unsure & 18 & 4 \\
Missing values & 41 & 9 \\
Retail/Wholesale & 15 & 3 \\
\hline Manufacturer & $\mathbf{4 4 4}$ & $\mathbf{1 0 0}$ \\
Service & 116 & 26 \\
Other & 39 & 9 \\
Missing values & 181 & 41 \\
\hline Industry operating & 55 & 12 \\
& 53 & 12 \\
\hline
\end{tabular}

\section{Empirical results}

The mean scores, evident in Table 4, determined the extent to which the respondents in general, agreed or disagreed with certain statements. The factor management abilities obtained the highest mean score of 4.1296, and the factor rewards the lowest mean value of 2.8581. According to literature (see for example De Vos et al., 2005: 235), if the standard deviation is high, the values are more dispersed. Table 3 also highlights the standard deviation scores. In this instance, the high standard deviation scores indicated that the respondents varied extensively with regard to their perceptions of the presence of the predetermined motivational factors. The highest standard deviation score was 0.8619 for rewards and the lowest score was 0.6211 for working conditions. 
Table 4: Motivational factors - Mean and standard deviation scores

\begin{tabular}{|l|l|l|}
\hline Factors & Mean & Std. Dev. \\
\hline Rewards & $\mathbf{2 . 8 5 8 1}$ & .8619 \\
\hline Working conditions & 4.0955 & .6211 \\
\hline Management abilities & $\mathbf{4 . 1 2 9 6}$ & .7530 \\
\hline Employee participation & 3.8268 & .8068 \\
\hline Company policies & 3.7538 & .8401 \\
\hline Recognition and feedback & 3.5767 & .8308 \\
\hline Job interest and importance & 3.7842 & .6961 \\
\hline
\end{tabular}

Table 5 presents the Pearson correlation coefficients and linear regression results obtained in the empirical investigation. The Pearson correlation coefficients and the linear regression illustrate the significantly positive relationships between all the predetermined motivational factors and employee satisfaction, as well as with employee commitment at the $95 \%$ confidence level. The strongest relationship was that between job interest and importance and employee satisfaction $(r=0.685)$, and the weakest that between rewards and employee satisfaction $(r=0.429)$. All the relationships between the predetermined motivational factors and employee commitment were also shown to be significantly positive. The strongest relationship was that between employee commitment and job interest and importance $(r=0.641)$, and the weakest that between employee commitment and rewards $(r=0.402)$.

Table 5: Motivational factors in relation to employee satisfaction and employee commitment Pearson correlation coefficients and linear regression results

\begin{tabular}{|l|l|l|l|l|}
\hline \multirow{2}{*}{ Factors } & \multicolumn{2}{|l|}{ Employee satisfaction } & \multicolumn{2}{l|}{ Employee commitment } \\
\cline { 2 - 5 } & $\begin{array}{l}\text { Pearson } \\
\text { correlation }(\boldsymbol{r})\end{array}$ & $\mathbf{R}$ Square $\left.\mathbf{( R}^{\mathbf{2}}\right)$ & $\begin{array}{l}\text { Pearson } \\
\text { correlation }(\boldsymbol{r})\end{array}$ & $\mathbf{R}$ Square $\left(\mathbf{R}^{\mathbf{2}}\right)$ \\
\hline Rewards & $\mathbf{4 2 9}$ & $\mathbf{. 1 8 4}$ & $\mathbf{. 4 0 2}$ & $\mathbf{1 6 2}$ \\
\hline Working conditions & .571 & .326 & .611 & .373 \\
\hline Management abilities & .572 & .327 & .563 & .317 \\
\hline Employee participation & .647 & .418 & .586 & .343 \\
\hline Company policies & .545 & .297 & .528 & .279 \\
\hline Recognition and feedback & .652 & .426 & .609 & .371 \\
\hline Job interest and importance & $\mathbf{. 6 8 5}$ &. $\mathbf{4 6 9}$ & $\mathbf{. 6 4 1}$ &. $\mathbf{4 1 1}$ \\
\hline
\end{tabular}

The linear regression analysis showed that there were highly significant relationships between each of the seven predetermined motivational factors and employee satisfaction and commitment. It is evident that the study confirmed the existence of all 14 relationships suggested by the theoretical model as presented in Figure 1. Therefore, all the hypotheses $\left(\mathrm{H}_{0}{ }^{1}-\mathrm{H}_{0}{ }^{14}\right)$ can be rejected, since moderate positive relationships exist between the seven motivation factors (independent variables) and employee satisfaction and employee commitment (dependent variables). Table 6 provides a ranking of the predetermined factors from the strongest to the weakest correlation for both employee satisfaction and employee commitment. 
Table 6: Ranking of motivation factors according to correlation strength for employee satisfaction and employee commitment

\begin{tabular}{|l|l|l|}
\hline Rank & Employee satisfaction & Employee commitment \\
\hline 1 & Job interest and importance $(0.469)$ & Job interest and importance $(0.411)$ \\
\hline 2 & Recognition and feedback $(0.426)$ & Working conditions $(0.373)$ \\
\hline 3 & Employee participation $(0.418)$ & Recognition and feedback $(0.371)$ \\
\hline 4 & Management abilities $(0.327)$ & Employee participation $(0.343)$ \\
\hline 5 & Working conditions $(0.326)$ & Management abilities $(0.317)$ \\
\hline 6 & Company policies $(0.297)$ & Company policies $(0.279)$ \\
\hline 7 & Rewards $(0.184)$ & Rewards $(0.162)$ \\
\hline
\end{tabular}

The strongest correlations for both employee satisfaction and commitment were found to be job interest and importance. Thus, in order for firms to increase both employee satisfaction and commitment, it is important to focus on employees' interest in their jobs and their value or the importance attached to their jobs. Questions that formed part of this factor related to items such as:

- interesting, exciting and challenging jobs;

- the importance of the individual's job in relation to the survival of the business;

- job specialisation and rotation;

- number of activities performed, and

- authority and control.

With employee satisfaction, recognition and feedback had the second strongest correlation, followed by employee participation, management abilities and working conditions. With employee commitment, the second strongest correlation was that of working conditions. In addition, recognition and feedback, employee participation and management abilities were important in order to increase employees' commitment levels. The two weakest correlations for both employee satisfaction and commitment were rewards and company policies. Rewards had the weakest correlation with employee satisfaction and commitment, although many individuals mistakenly assumed that monetary rewards were the main motivational factor.

\section{SUMMARY AND CONCLUSIONS}

This study has provided a brief overview of the perception of employees in small businesses about the motivational factors that need to be present in order to keep them satisfied and committed. Taking into account the high failure rate of small businesses, it may be assumed that managers lack some of the essential know-how to manage a business successfully. Human resources form the cornerstone of any business, and care should be taken to ensure employees' "happiness" within the business, in order to find and retain quality employees. What will happen to businesses that are burdened with employees who are not motivated, satisfied or committed? The consequences are likely to be detrimental. The manner in which managers deal with their employees, in terms of motivation, satisfaction and commitment, has an impact on the long-term success of the business. Business managers should acknowledge the value of ensuring that employees remain satisfied and committed as a major influencing factor in terms of the country's ability to prosper.

Small businesses should implement the seven predetermined motivational factors discussed in this study in creative ways, in order to have a positive effect on motivational levels. Such a positive effect will increase employee satisfaction and commitment levels. Research shows that satisfied employees will have a positive influence on business performance. In addition, according to research, committed employees are the hallmark of a successful business. Ultimately, employees who are satisfied and committed will contribute to the greater survival of small businesses in South Africa, which will help to ensure economic prosperity in the country. 


\section{RECOMMENDATIONS}

A number of recommendations can be made with regard to the relationships between the seven predetermined motivational factors and employee satisfaction and commitment, which are discussed below.

With regard to the high failure rate of small businesses, it is suggested that care be taken when managing the human capital of businesses. Management may lack the skills and know-how about managing a business's resources - including human resources - properly. It is vital that managers should be aware of the motivational factors that will influence the satisfaction and commitment of employees, which in turn will influence the success of the business. Small businesses should be given every encouragement and means of guidance to help improve the business's performance in the market-place. In this regard, various institutions, both private and public, can play a supporting role by assisting small business managers in "managing" their employees, by making programmes available to SMMEs. This will empower small business managers to become more knowledgeable about how to keep their employees satisfied and committed, by applying the motivational factors in accordance with the findings of this study.

As seen from the empirical findings, although a positive relationship exists, rewards have the weakest correlation with employee satisfaction and commitment. Rewards should therefore not be the main motivational tool to ensure employee satisfaction and commitment. Merely receiving a salary every month will not necessarily cause employees to be satisfied or committed. Rewards can take various forms, such as wages/salaries, pension schemes, health insurance, bonuses, commission and share options. The moment money is seen as a right, it will lose its motivational value and will not contribute to satisfaction and commitment. In order to have a positive effect on employee satisfaction and commitment, extra money must be given over and above the recognition by the manager of those employees who have performed exceptionally well. There must thus be a clear link between performance and reward. Employees must be aware of the fact that if they excel in their performance, it will lead to a valued reward.

The positive relationship between working conditions and employee satisfaction and commitment proves that it is crucial to create a work climate that is morale-boosting. The employees' workplace and the equipment they use must be safe and clean. It is necessary that pleasant relationship should exist between employees and employers, and that employees are required to work reasonable hours. All this will contribute to higher employee satisfaction and commitment levels.

Management abilities also have a positive relationship with employee satisfaction and commitment. It is important that managers should listen to and support their employees, create conditions under which employees feel inspired to work hard, avoid negativity, take a sincere interest in each individual employee, model enthusiasm, show appreciation for employees' good work, and demonstrate confidence in their employees. Managers must identify the basic needs of their employees in order to attempt to apply the motivational factors so as to fulfil such needs. Employees are generally more motivated by a democratic management style than an autocratic management style. Managers should therefore consult their employees when making plans or taking decisions, in order to ensure greater employee participation.

It has been established that a there is a positive relationship between employee participation and employee satisfaction and commitment. In order to improve satisfaction and commitment, employees should participate in the goal-and-objective- setting process of a business. Employees often have meaningful ideas and suggestions and should be encouraged to act on their own initiative. Employees should receive regular feedback on how well they are doing in pursuit of the goals of the business. Managers should grant employees the opportunity to share leadership responsibilities and exercise authority, power and control. When employees feel that their opinions, ideas and suggestions are valued, there will be higher levels of satisfaction and commitment.

The positive relationship between company policies and employee satisfaction and commitment signify the importance of reliable and comprehensive systems that should be in place in a business, in order to motivate 
employees. Examples of systems that should be adhered to are compensation systems, employee performance systems, equity systems, and organisational policies and procedures. These systems ensure a clear understanding and equitable treatment of employees. Company policies and systems should create a climate that reinforces values concerning performance, and should communicate acceptable ways of behaviour.

It has been proved that recognition and feedback are positively related to employee satisfaction and commitment. Thus, in order to ensure higher levels of employee satisfaction and commitment, managers must acknowledge the achievement and success of a particular task by the employees concerned. Managers must demonstrate appreciation for a job well done. Acknowledgements can be casual or formal, and can be simply a word of appreciation, a personal note, a trophy or a promotion. In order to ensure higher levels of satisfaction and commitment, work well done should always be recognised, and a manager should never hesitate to praise an employee.

The most significant positive relationship was determined to be that between job interest and importance and employee satisfaction and commitment. Managers should therefore do everything in their power to ensure that employees are placed in jobs that they perceive as interesting, meaningful, exciting, challenging, and critical for the survival of the business. This can be done in a variety of ways, such as job enlargement, job rotation and job enrichment. Employees should be able to apply a variety of skills in their job, understand their tasks and the importance of their work, have control over their work, be responsible for the results, and receive feedback in terms of the work that they have done. As proved in the simple linear regression analysis, motivation, quality of work, performance output, employee satisfaction and commitment and absenteeism will all improve if jobs include elements focusing on job interest and importance.

To summarise, with regard to employee satisfaction and commitment levels, the following recommendations can be made:

- Levels of satisfaction and commitment can be continually developed and improved through training of managers on how and to what extent to apply motivational factors.

- Managers need to communicate with employees and obtain feedback on what their needs are and how they perceive their current job situation. This will enable managers to determine what each employee wants out of his/her job, and which motivational factors each employee perceives as the most important.

\section{ACKNOWLEDGEMENTS}

- A special word of thanks to Ms Elda van Vuuren, for her assistance with the literature overview and interpretation of the empirical results.

- The authors would also like to thank the fieldworkers who collected the data for this research. 


\section{REFERENCES}

Bosch JK, Tait M \& Venter E. 2006. Business management: An entrepreneurial perspective. Port Elizabeth: Lectern.

Burns RB \& Burns RA. 2008. Business research methods and statistics using SPSS. Los Angeles: Sage.

Carrell MR, Grobler PA, Elbert, NF, Marx M, Hatfield RD \& Van der Schyf S. 1998. Human resource management in South Africa. $1^{\text {st }}$ Edition. New Jersey: Prentice Hall Inc.

Collins J \& Hussey R. 2003. Business research. $2^{\text {nd }}$ Edition. New York: Palgrave McMillan.

Cronjè GJ de J, Du Toit GS \& Motlatla MDC. 2000. Introduction to business management. $5^{\text {th }}$ Edition. Cape Town: Oxford.

Daft RL. 2008. New era of management. USA: Thomson South Western.

De Vos AS, Strydom H, Fouché, Delport CSL. 2005. Research at grass roots: for the social sciences and human service professions. Pretoria: Van Schaik.

Goodworth CT. 1984. How to be a super-effective manager. $1^{\text {st }}$ Edition. England: Anchor Brendon Ltd.

Hair JF, Babin B, Money AH \& Samouel P. 2003. Essentials of business research methods. USA: Leyh Publishing.

Ireland RD, Hoskisson RE \& Hitt MA. 2009. The management strategy: Concepts. $8^{\text {th }}$ Edition. USA: South Western Cencage Learning.

Lancaster G. 2005. Research methods in management: a concise introduction to research in management and business consultancy. Great Britain: Elsevier Butterworth-Heinemann.

Lewis JD. 2002. Promoting growth and employment in South Africa. Africa region working paper series 32 [Online] Available: http://www.worldbank.org/afr/wps/index.htm [Accessed 15 June 2009].

Lind DA, Marchal WG \& Wathen SA. 2008. Basic statistics for Business and Economics. $6^{\text {th }}$ Edition. Boston: McGraw-Hill Irwin.

Louw L \& Venter P. 2006. Strategic management: Winning the Southern African workplace. Cape Town: Oxford.

Lynas MG \& Dorrian AP. 1987. Managing the smaller firm. $1^{\text {st }}$ Edition. Johannesburg: Southern Book.

Macleod G. 1999. Starting your own business in South Africa. $9^{\text {th }}$ Edition. Cape Town: Oxford.

Mol A. 1993. Help! I'm a manager. $3^{\text {rd }}$ Edition. Cape Town: Tafelberg Publishers Limited.

Munyanyiwa T. 2009. SMEs key to economic growth, recovery, The Financial Gazette. 28 May. [Online] Available: http://www.financialgazette.co.zw/index.php?option=com_content\&view=article\&id=1020\%3As mes-key-to-economic-growth-recovery\&catid=77\%3Acompanies-a-markets\&ltemid=89 [Accessed 15 May 2010].

Oldcorn R. 1989. Management. $2^{\text {rd }}$ Edition. Basingstoke, Harris: Macmillan. 
Reece RC. 2001. Sibling Partnerships one for all and all for one. [Online] Available: http://www.fambizadvice.com [Accessed 28 February 2007].

Robbins SP \& Coulter M. 1999. Management. $6^{\text {th }}$ Edition. USA: Prentice-Hall Inc.

Sheldon B. 2006. Are happy employees motivated employees? [Online] Available: http://www.employeremployee.com/happymotivated.html [Accessed 29 May 2009].

Vil-Nkomo S. 2005. The importance of SMMEs to the economic development of Africa, African Business Journal. Issue 21. [Online] Available: http://www.tradersafrica.com/ [Accessed 29 May 2009].

Wadula P. 2005. Why SA's small businesses stay that way, Business Day. 11 January. [Online] Available: http://www.businessday.co.za/bday/content/direct/1,3523,1781349-6078-0,00.html. [Accessed 15 June 2009].

Watson J. 2003. The potential impact of assessing advice on SME failure rates. A paper for the Small Enterprise Association of Australia and New Zealand $16^{\text {th }}$ Annual conference, Ballarat, 28 September -1 October 2003.

World Business Council for Sustainable Development. 2007. Promoting small and medium enterprises for sustainable development. Switzerland: Atar Roto Presse SA.

Zikmund WG. 2003. Business research methods. $7^{\text {th }}$ Edition. USA: Thomson South Western. 